\title{
Warfare, Political Identities, and Displacement in Spain and Colombia
}

\author{
Laia Balcells ${ }^{\mathrm{a}} \&$ Abbey Steele ${ }^{\mathrm{b}}$
}

\section{Acknowledgements}

We thank Ana Arjona, H. Zeynep Bulutgil, Clara Cortina, Matthew Kocher, Roger Petersen, and Seiki Tanaka for comments and suggestions on previous versions of this paper. An earlier version of this paper was presented at the Association for the Study of Nationalities World Convention, New York City, April 2012, and at the Institute for Economic Analysis, CSIC. We also thank Joshua Borkowski, Istvan-Levente Fazakas and Spencer Dorsey for valuable research assistance. Laia Balcells acknowledges financial support from the Harry Frank Guggenheim Foundation and the Niehaus Center for Globalization and Governance (NCGG) at Princeton University. Abbey Steele acknowledges the support of a National Science Foundation graduate fellowship, the Fulbright DDRA Program, and The MacMillan Center for International and Area Studies at Yale University, which supported fieldwork in Colombia 2006-2007 and 2008, as well as the Air Force Office of Scientific Research (AFOSR) under Award No. FA9550-09-1-0314.

\footnotetext{
${ }^{a}$ Duke University. 140 Science Drive, Durham, NC 27708, USA. Phone: 919-660-4367. Fax: 919-660-4344. Email: laia.balcells@duke.edu (Corresponding author).

${ }^{\mathrm{b}}$ The Maxwell School, Syracuse University. Permanent Address: University of Amsterdam. Nieuwe Achtergracht 166, 1018 WV Amsterdam, The Netherlands. Phone: +31.62.564.3672. Fax: +31.20.525.2086. Email: abbey.steele@uva.nl. The authors are listed alphabetically; equal authorship implied.
} 


\begin{abstract}
This paper explores the causes of displacement during civil wars. Recent scholarship has shown that conventional civil wars - those in which forces are relatively balanced - and irregular civil wars - those in which one side is substantially stronger than the other - exhibit different patterns of violence. We hypothesize that, while the mode of violence differs, the form of displacement should be consistent across the wars: displacement is a tactic of war that armed groups use to conquer new territories. By expelling civilians associated with rivals, armed groups improve their odds of gaining control of contested territory. This implies that members of a group are targeted for displacement because of their identity and presumed loyalties. We test the theory using two fine-grained datasets on individuals displaced during a conventional civil war, in Spain (1936-1939), and an irregular civil war, in Colombia (1964-). In both cases, the war cleavage was ideological and reflected in national elections: the locations where political parties received support indicated which populations were sympathetic to rivals. In both civil wars, we observe higher levels of displacement in locations where more sympathizers of rival armed groups reside. The article is the first comparison to our knowledge of the sub-national dynamics of displacement within two different civil wars and it shows that the microfoundations of displacement are similar across types. Finally, the article explains macro-level differences with a coherent micro-level framework.
\end{abstract}

Keywords: violence, civil war, displacement, political identity, Colombia, Spain

Abbreviated title: Displacement in Spain and Colombia 


\section{$\underline{\text { INTRODUCTION }}$}

Since WWII, tens of millions of people have left their homes, regions, and countries during war. The United Nations High Commission for Refugees (UNHCR) recently estimated that nearly 60 million people are currently displaced - more than any other time in history (UNHCR 2015). Displacement - civilian migration during war that is provoked, directly or indirectly, by the actions of one or several armed groups (Steele 2010) - is a serious humanitarian and political challenge for countries undergoing conflict, as well as for their neighbors (Salehyan \& Gleditsch, 2006). Understandably, media and advocacy groups tend to focus on how many people flee violence, and potential interventions to address the problem - often leaving the underlying causes of displacement unexplored. Refugees are perceived as victims of violence, but unrelated to it. For example, Azam and Hoeffler argue that the displaced population "can be regarded as the natural fall-out of the damage inflicted by each army to the opposing group" (2002: 473). Yet, refugees are also political actors, whose identities and loyalties, we argue, are crucial to their displacement.

The existing refugee literature has tended to focus on factors that lead civilians to leave their homes, ranging from violence to household characteristics. ${ }^{1}$ However, recent sub-national studies of ethnic cleansing have explored the conditions under which armed groups seek to expel members of rival ethnic groups and have found substantial variation in the timing and location of cleansing (Bulutgil, 2009; Ron, 2003; Weidmann, 2011). Variation in armed group behavior in non-ethnic civil wars has received comparatively little attention. However, armed groups target civilians associated with their rivals based on ethnic group, sect, tribe, profession, or political affiliation - whatever indicates loyalties to one side or the other engaged in fighting. Abbey Steele (2009) has called this "collective targeting". ${ }^{2}$ Collective targeting should account for an 
important component of overall displacement, even in non-ethnic civil wars.

This paper advances the literature by testing the hypothesis that displacement follows collective targeting even in non-ethnic civil wars. To do so, we use local-level electoral results from two very different civil wars, and exploit intra-country variation in combination with a small-n comparison of the cases: Spain (1936-1939) and Colombia (1964-). This approach allows us to capture the micro-foundations of displacement across two wars that display distinct characteristics, but that are similar in that they are both non-ethnic civil wars and both present important levels of displacement. The Spanish Civil War was possibly the first contemporary civil war witnessing mass displacement as a war tactic (Prada, 2010). Historians have estimated that over 440,000 people left Spain during the conflict and right after its end (Marrus, 2002). The decades-long irregular civil war in Colombia has produced one of the largest populations of internally displaced people (IDPs) in the world, estimated at roughly 6 million (IDMC 2014). Importantly, elections were held in both cases that indicated civilians' political loyalties.

While both wars involve political loyalties rather than ethnic identities, they display different forms of warfare, or "technologies of rebellion" (Kalyvas \& Balcells, 2010). Scholars have found that lethal violence follows different patterns depending on war type (Kalyvas, 2006; Balcells, 2010); we expect, in contrast, that displacement across these wars will share similarities. In addition, while the micro-foundations of displacement are consistent across war types, we reason that warfare type influences the timing and location of displacement, leading to different expectations in irregular and conventional civil wars. We argue that in irregular civil wars such as the Colombian one, characterized by fluid frontlines and fragmented military control, displacement will be provoked by armed groups (and, mostly, incumbents) anywhere that contestation takes place, and where "rival" civilians are identified. In conventional civil wars 
such as the Spanish one, displacement will instead be related to changes in the frontline, where fully controlled areas become contested ones. In conventional wars, frontlines are overall more stable and less fluid than in irregular one: for this reason, we expect displacement to be more territorially and temporally concentrated in areas and phases of conquest. We argue that in both cases, cleansing territories of suspected enemies will be instrumental for groups attempting to conquer them. The study of the Spanish and Colombian civil wars allows us to show that dynamics of cleansing are not restricted to ethnic conflicts, but also take place in the context of civil wars fought along ideological lines.

To test the implications of the theory, we use microlevel data on displacement and electoral results within the Spanish and Colombian civil wars and integrate qualitative evidence as well. The quantitative analyses account for spatial dependence among units within the cases, and indicate strong support for our hypothesis: displacement was higher in scale where electoral results indicated higher proportions of political rivals at the municipal level.

The next section of the paper presents the theoretical framework and our main hypothesis. We then present the cases and test the hypothesis using novel sub-national data from Spain and Colombia. The following section discusses the results and their implications for the timing and scale of wartime displacement. The last section concludes.

\section{$\underline{\text { THEORY }}$}

The timing and scale of civilian displacement varies within and across wars. What explains the patterns? The literature on displacement has focused on macro-level factors that influence refugee flows cross-nationally. Despite its relevance, a drawback of the existing literature is that violence is an exogenous factor, with the main conclusion being that more violence leads to 
higher levels of displacement (e.g., Schmeidl 1997; Weiner 1998; Davenport et al 2003; Moore and Shellman 2006). Moving the analyses to the micro level, Ibáñez (2008) and Adhikari (2012) consider how households' characteristics within Colombia and Nepal, respectively, produce variation in displacement; Lozano-Garcia, et al. (2010) also analyze displacement in Colombia and argue that violence is the main determinant of what they call the journey to safety. Though the theoretical conclusions are consistent with the earlier cross-national analyses, the micro-level approach constitutes an advance in the precision of the analyses.

The literature on ethnic cleansing has considered an additional type of variation: not just the timing and scale, but also what types of civilians are displaced. It differs from the displacement literature because elites' and armed groups' behavior, rather than civilians', is the focus of explanation. Some works emphasize the conditions under which ethnic cleansing can emerge (Mann, 2005; Bulutgil 2015). Others such as Ron (2003), Bulutgil (2009) and Weidman (2011) focus on variation within the Balkan wars and find that community-level and political factors shape the likelihood that the targeted ethnic group will in fact be cleansed. The focus on within-war variation in targeting constitutes an important analytical and empirical advance.

Bridging the literatures on displacement and ethnic cleansing, we argue that armed groups use violence to expel civilians they perceive to be disloyal in order to conquer a territory. ${ }^{3}$ Like ascriptive traits such as those associated with ethnic groups, we argue that political identities also can be used to infer where people's loyalties lie. Most people hold multiple identities, but during conflict some identities become more salient than others; the identities corresponding to the macro-cleavage of the war are those that become relevant for armed groups' identification of potential threats. People may collaborate with an armed group because of their political beliefs, or they may do so because it is safer given their association with a political party, 
group, or identity (Kalyvas \& Kocher, 2007). Either way, armed groups and fellow civilians often infer who is going to collaborate with whom based on group identities like political affiliation. And targeting follows these identities.

When armed groups target members of the disloyal group, the safety of individuals who share a targeted trait depend on everyone else similarly targeted (Steele, 2009). Given sustained violence directed at their group, individuals have strong incentives to leave, which only increase if others begin to do so: that is, it creates a cascade effect. Importantly, the violence and accompanying group dynamic can trigger a range of individual-level mechanisms leading people to leave their homes. Some individuals will fear the possibility of violence more than others, and opt to leave before shots are even fired. Others may wait for a more immediate threat to their safety, or leave only when they have made arrangements to stay with relatives elsewhere. We do not aim to parse these possible mechanisms among individuals. Instead, we assume that armed groups anticipate that segments of a targeted group are likely to leave given threats and violence, and will implement collective targeting to generate displacement of a subset of the community for a strategic advantage. The tactics that armed groups employ range from lethal violence directed at members of a group to threats of lethal violence if people do not leave, such as graffiti warnings and leaflet distribution.

Given the tactics of collective targeting, we argue that violence is often employed in order to produce displacement, rather than independent of it. The logic applies to irregular civil wars because insurgents depend on civilians for survival, and targeting them is an effective way to target insurgents (Valentino, et al. 2004; Kalyvas 2006). At the same time, the logic also applies to non-irregular wars, but only when territory is militarily contested. In this context civilians can be particularly helpful to their group (they can provide much-needed intelligence, 
and run interference with the rival armed group), and thus we can expect cleansing dynamics to emerge. When the territory is not militarily contested, that is in rearguard territories of conventional civil wars, individuals are unlikely to be targeted for short-term tactical reasons, because they are not integral to which armed group wins. Furthermore, when an armed group has full control of a territory, it can selectively kill supporters of the enemy, which is safer than displacing because an expelled person could provide valuable intelligence to the enemy.

But, in a context of military contestation, why would groups resort to displacement instead of mass killing? We argue that given the goal of the armed group to gain territorial control, strategic displacement is less costly than mass killing for two reasons. First, at least in contemporary civil wars, mass killing invites condemnation that could lead to intervention, and jeopardize an armed group's ability to control a territory. Second, because displacement is frequently perceived to be a by-product of violence, armed groups, especially state armed forces, can deny responsibility more easily than when using lethal violence.

In short, we argue that in civil wars displacement is likely to be used as a cleansing tactic where and when there is military contestation, and that this is the case in both ethnic and nonethnic civil wars, and in both irregular and conventional civil wars. From this framework, we derive the following observable implication: during civil war, displacement will be highest in areas where residents are perceived to be loyal to an armed group, when a rival group contests the territory.

\section{$\underline{\text { EMPIRICS }}$}

We use novel empirical evidence from Spain and Colombia in order to test our argument. These are two useful cases for comparing sub-national patterns of displacement because --while they 
are both ideological civil wars-- they are quite different in terms of warfare technology. Spain was a conventional civil war, while Colombia is an irregular one. Additionally, the time span between them is substantial: the Spanish civil war took place between 1936 and 1939, while the Colombian one started in 1964 and continues today. If we find evidence of similar displacement patterns within these wars despite these differences, it will constitute strong support for the argument. A final advantage to using these cases is that elections were held in both cases, previous to events of violence and displacement, and electoral results constitute a good proxy for the political composition of localities. ${ }^{4}$

The Spanish Civil War began as a military coup against a legally constituted democratic government. It lasted for almost three years (18 July 1936-1 April 1939) and generated around 800,000 deaths (including civilians and combatants). Two main political blocs fought the war: the army of the Republican government, the Loyalists, which also included militias of political parties, trade unions, and the International Brigades; and the army of the rebels, the Francoists or Nationalists, which also included factions of the regular army and various militias. The Nationalists won the war, and Spain became a military dictatorship led by General Francisco Franco that lasted until 1975, when Franco died and a successful transition process to democracy began.

The main cleavage of the civil war in Spain was a left-right cleavage that reflected the electoral contestation of the February 1936 elections, in which two coalitions grouping left- and right-wing candidates competed (the Popular Front, on the left, and the CEDA, on the right). The religious cleavage fully overlapped with the left-right cleavage: traditional Catholics were aligned with the right. In Catalonia and the Basque Countries, ethnic cleavages cross-cut political ones, but ideology (and not ethnicity) was the master cleavage before and after the civil war 
outbreak within these regions. ${ }^{5}$ High levels of political mobilization, which revealed political identities at the local level, preceded the February 1936 elections in Spain.

In Spain, there is evidence showing that indirect violence (i.e. bombings) was perpetrated based on political identities, and that groups intentionally targeted enclaves of the enemy (Balcells, 2016) in territories they did not control militarily. These bombings were an example of collective targeting, which we argue produced displacement. As armed groups entered new territories, they targeted enemies' enclaves, spread fear (Preston, 2011), and promoted displacement to gain control of these territories.

The civil war in Colombia has a long history featuring many organizations aligning roughly along a left-right cleavage. The two largest leftist guerrilla groups that still exist today, the Revolutionary Armed Forces of Colombia (Fuerzas Armadas Revolucionarias de Colombia - FARC) and the National Liberation Army (Ejército de Liberación Nacional - ELN) emerged in the 1960s following a civil war along partisan lines known simply as The Violence. ${ }^{6}$ In the early 1980s, a few military officers started to support regional paramilitary groups, operating in areas of the country where local elites and narco-traffickers sought to combat insurgents (Romero, 2000). After an intensification of violence between the "left" (i.e., insurgent organizations) and the "right" (i.e., paramilitary groups and the military) throughout the 1990 s and early $2000 \mathrm{~s},{ }^{7}$ the majority of the paramilitary blocs agreed to demobilize between 2003 and 2006. Since then, groups known as BACRIM (“criminal bands") compete for abandoned territory and drug trafficking routes, and in some cases engage in political violence against victims' rights leaders. While insurgents' strength has declined from its peak in the 1990s, they remain viable through access to narcotics and extortion revenue. The FARC entered peace talks with the Santos administration (2010-), and the ELN continues informal talks with the government. An estimated 
200,000 people have been killed in Colombia since the 1960s (Centro Nacional de Memoria Histórica, 2012).

As with many irregular civil wars that do not feature an ethnic cleavage, in Colombia it is impossible to directly observe insurgent supporters. Colombia's democratic institutions have persisted in spite of the civil war, with the armed groups variously on the sidelines, influencing turnout and outcomes (López, 2010), and creating political parties. As part of a negotiated agreement with the government, in 1985 the FARC formed the Unión Patriótica (UP), a political party that contested the presidential election in 1986, and participated in local mayoral (alcalde) elections when they began in 1988. Beginning in May 1985, all fronts of the FARC were ordered to organize the UP in their area through "Juntas Patrióticas" (JPs) (Dudley, 2006: 60). When party members and candidates became targets of assassins starting in 1986, the leaders of the UP distanced themselves from the FARC, questioning the so-called "war on all fronts." The rift, however, did not alter the perception that the UP's supporters were FARC sympathizers (Giraldo, 2001). Paramilitary groups used the information revealed by local elections, and provided by local elites threatened by the success of the UP, to undertake the conquest of FARC-influenced areas. While individuals' votes were secret, local candidates were elected to represent specific neighborhoods or rural communities (Reiniciar, 2006; Dudley, 2006). As a result, it was straightforward to infer which areas supported the UP. We argue that these areas were more likely to be targeted than others by paramilitaries seeking to gain control of the territory. ${ }^{8}$

\section{$\underline{\text { Analyses }}$}

We now turn to tests of our hypothesis with econometric analyses, to explore the determinants of variation in displacement across localities for both Spain and Colombia. We present each case independently and return to the implications of both sets of results in the discussion section. In 
the analyses, displacement is the dependent variable, which is measured by the number of people who leave a locality. Our main independent variable is the percent of perceived supporters of the rival armed group at the local level. As a proxy for this, we use percent electoral support for a bloc in both cases (percent support for the left-wing coalition in the prewar 1936 elections in Spain; average percent support for UP in the 1990, 1992, 1994 and 1997 elections in Colombia the period before displacement was registered). This is an adequate proxy in these two cases, because the political cleavages match the war cleavages. In both cases, we use a similar set of control variables, but the indicators vary slightly due to data collection constraints. ${ }^{9}$ We use Latitude and Longitude of the centroids of the localities to test for spatial autocorrelation and because we find that there is spatial autocorrelation in the data--- we run spatial lag and spatial error models to test our hypothesis.

\section{$\underline{\text { Spain }}$}

Despite the importance of the phenomenon, data on the displaced during the Spanish Civil War are still fragmentary. Most studies on refugees within Spain have used unsystematic, patchy data at the county level or they simply are local case studies; partly as a consequence of the scarcity of data, no systematic study of displacement has been done to date. In this paper, we focus on Catalonia, the only region for which we could obtain reliable estimates of displacement at the local level. Catalonia was a rearguard territory under Republican control during a relatively long period of the civil war, before the Nationalist army eventually conquered the territory. Lethal violence against civilians took place in Catalonia in two stages: first (from July 1936 to 1938/39), violence was perpetrated by leftist militias and the Republican army; later, the Nationalist army and right-wing militias perpetrated violence during the period of conquest and after it. The Nationalists also perpetrated strategic aerial bombings in across most of the Catalan territory 
since 1937 and until they occupied the region in February 1939. A high number of people were displaced in the region, and the scale varied across the territory. The region also presents variation in variables such as urbanization, political support for the right/left and geographical characteristics. Because of this wide variation in the independent and dependent variables, the results obtained in this region are likely to travel well to other regions of Spain.

For the purposes of this paper, we will focus on the displacement that took place at the end of the war in Catalonia, which was the most significant in terms of quantity: what we call 1939 Displacement. We do not have good estimates of the displacement that took place in 1936, which was less significant in numbers (see below). To estimate 1939 Displacement, we generate an index based on the difference in the local population censuses of 1940 and 1936, from which all those people who disappeared for reasons other than migration/exile and natural death are subtracted. ${ }^{10}$ The displacement index covers 654 municipalities; ${ }^{11}$ the minimum value is 0 , the maximum is 2,094, and the median is 34 individuals. The total estimated displaced in Catalonia is 56,520 , which represents $2.4 \%$ of the 1936 population census of the region. The index has the advantage of being the first estimate of displaced people in the Spanish Civil War for a significant number of localities; it has the disadvantage of being based on census data which have inevitable problems because of biases related to wartime, and which have an important number of missing cases. ${ }^{12}$ Figure 1 shows the distribution of this estimate across Catalan localities, which shows the significant variation in displacement within counties and provinces. 
Figure 1. Estimated Displacement in Catalonia (Spain), 1939

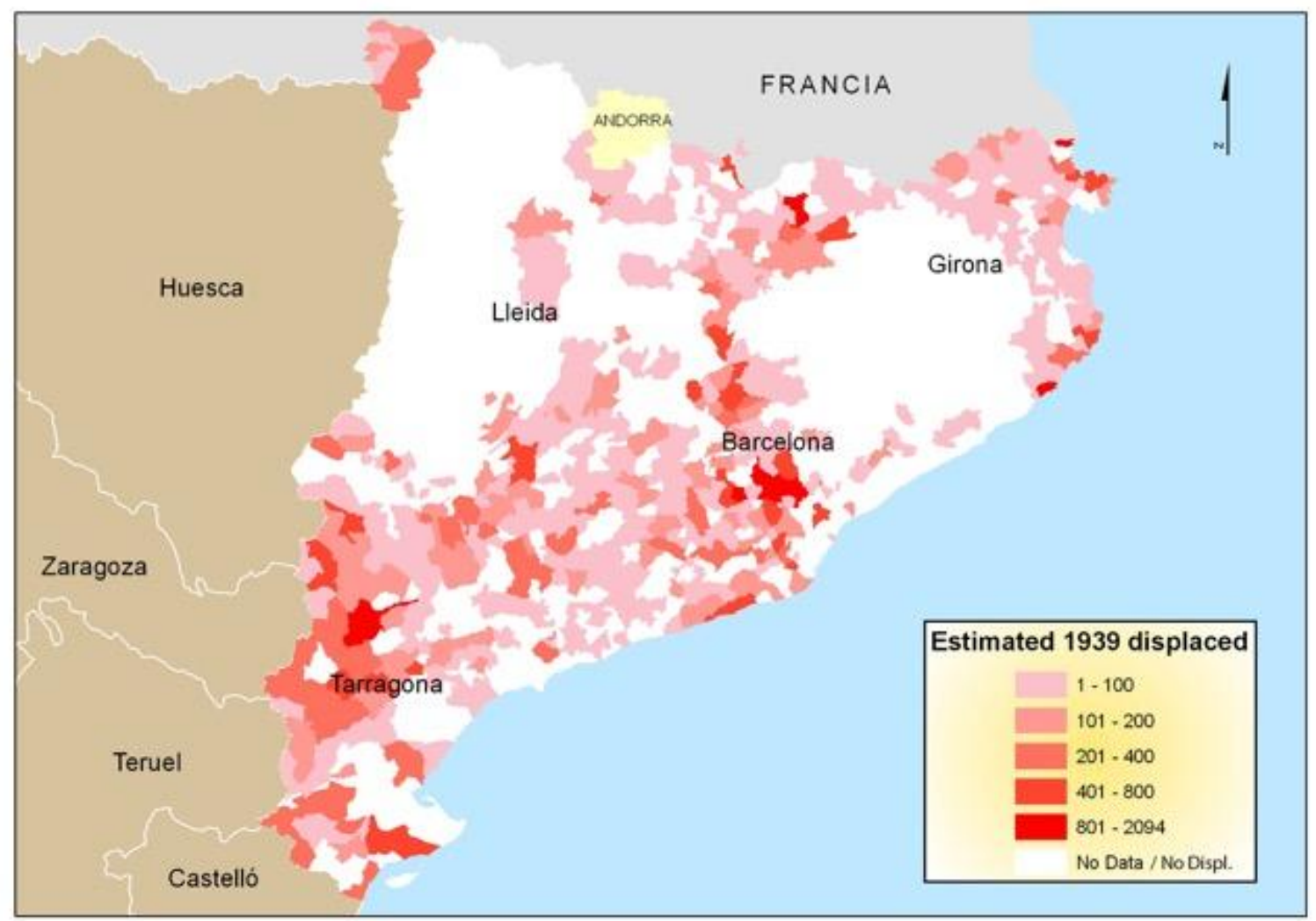

We expect leftist support at the local level to have a positive impact on collective targeting by the right, and therefore on displacement. The main independent variable in the models is Support left 1936, which is the percent support for the Popular Front in the 1936 general elections (Vilanova, 2005), at the local level. This captures in a precise way the relative number of leftist supporters in a locality. Figure 2 is a scatterplot of 1939 Displacement (in percent inhabitants of the locality) and Support Left, for all Catalan localities. The graph depicts a positive relationship between the proportion of leftists in a locality and local percent of displacement, which is consistent with our hypothesis. 
Figure 2. Estimated Percent Displaced (1939) and Percent Support Left (1936), Catalonia

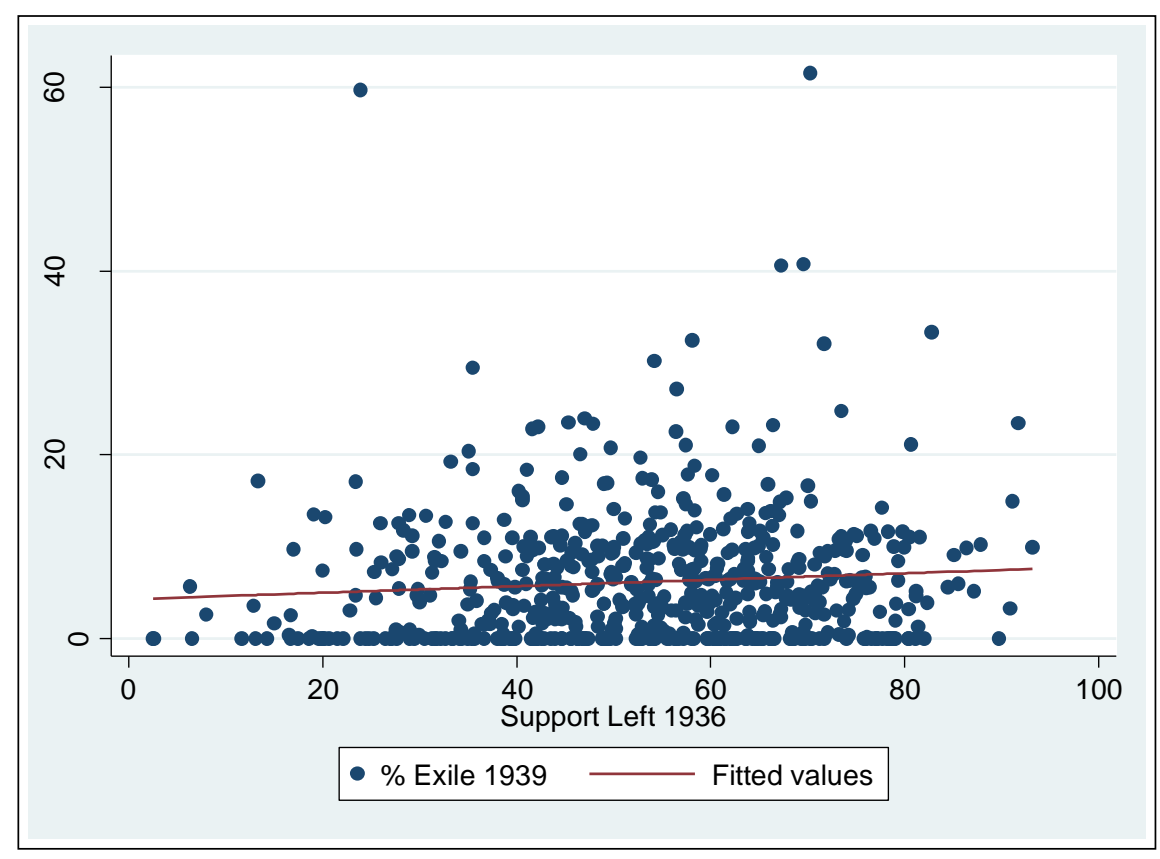

We use two additional proxies for leftist supporters: CNT Affiliation, which is the proportion of inhabitants affiliated with the CNT in a locality (CNT, 1936; Cucó Giner, 1970), and captures the presence of anarchists (i.e. leftist supporters); and UGT Affiliation, which is the proportion of inhabitants affiliated with the UGT, a socialist trade union, in a locality (UGT, 1931a, 1931b). Catholic Center is a dummy variable, with value 1 if the municipality had an archbishop in 1936, and 0 otherwise (Conferencia Episcopal Española), which measures the extent to which rightist supporters lived in a locality. Locations with archbishops had significantly more members of the clergy living in them than other localities, and active Catholics and members of the clergy sided with the Nationalists. Competition is an index from 0 (minimum parity) to 1 (maximum parity), measured with quadratic formula: 1-[(\%Vote Left36 $\%$ Vote Right/100)]. ${ }^{2}$ It captures the extent to which the locality was divided across the right-left 
cleavage line. We will include it in Model 2 to test for the alternative hypothesis that parity between groups, which accounts for violence in conventional civil wars (Balcells 2010), also explains displacement.

Additionally, we include in all models Elevation of the municipality, in meters, as a control variable (Institut Cartogràfic de Catalunya). Higher altitude localities were less accessible (i.e. further away from major roads), but they were also safer during wartime because they were less strategic from a military point of view. In the case of Catalonia, higher altitude also means increased opportunities to escape because the Pyrenees border France. Finally, we include Population, the number of inhabitants of the municipality in 1936 (SGE, Generalitat de Catalunya). This captures size of the municipality, which we expect to have a positive impact on the total number of refugees.

In addition to the independent variables measuring perceived disloyalty in a municipality, we include, in different models, measures of lethal violence at the local level in order to account for the potential relationship between killings and displacement. Executed Left is the total number of people executed by the left in a locality in the 1936-39 period (Solé i Sabaté, \& Villarroya, 1989). It captures the extent to which the locality was violent during the period of Republican control. People in localities where the left had perpetrated violence could be more fearful of retaliation by the incoming right-wing forces, and therefore could be more prone to flee. Clergy Killed is a dummy variable coded as 1 if any member of the clergy (e.g. priest, nun, bishop) was killed in the locality in the 1936-39 period, 0 if not (Solé i Sabaté, \& Villarroya, 1989). This also measures the extent to which the locality was violent in the Republican period and, more specifically, it captures anti-clerical violence, which was usually publicized and very visible to the inhabitants of the locality (de la Cueva, 1998). Bombings captures the extent to 
which the locality experienced indirect violence (Solé i Sabaté, \& Villarroya, 1986), which prompted displacement, as we have explained above. ${ }^{13}$ We do not include executions by the Nationalists because, in Catalonia, most of these killings took place when the war was already over and were therefore posterior to displacement.

Spatial autocorrelation can bias analyses with geographical data (Anselin et al. 2004). We check for spatial autocorrelation in our dependent variable and the I-Moran's statistic $(0.023$, significant at the $99 \%$ level -both in one-tail and two-tail tests) indicates that there is significant spatial autocorrelation that could bias naive regression results. We thus run two sets of spatial regression models: spatial lag models that take into account the neighbors' values of the dependent variable, and spatial error models that take into account spatial correlation in the error term. We have point data and we run different sets of spatial regression models; here we present the results of analyses with distance-based (inverse distance) weights matrix (distance band: 0.0 $<\mathrm{d}<=4.0$ ), row-standarized. As robustness checks, we have also run k-nearest neighbors analyses $(\mathrm{k}=2,3$, and 4$)$ and the results are consistent. 
Table 1. Spatial Lag Regression for 1939 Displaced in Catalonia

\begin{tabular}{|c|c|c|c|c|c|}
\hline & M1 & M2 & M3 & M4 & M5 \\
\hline \multirow[t]{2}{*}{ Support_left36 } & $0.94^{* * * *}$ & & $0.97^{* * * *}$ & $0.933^{* * * *}$ & $0.94^{* * *}$ \\
\hline & $(0.29)$ & & $(0.29)$ & $(0.28)$ & $(0.27)$ \\
\hline \multirow[t]{2}{*}{ CNT Affiliation } & $13.2^{* * * *}$ & $13.3^{* * *}$ & $12.7^{* * *}$ & $13.7^{* * *}$ & $13.3^{* * *}$ \\
\hline & $(3.87)$ & $(3.93)$ & $(3.38)$ & $(3.92)$ & $(3.86)$ \\
\hline \multirow[t]{2}{*}{ UGT Affiliation } & 0.013 & 0.23 & -1.90 & 0.36 & -0.046 \\
\hline & $(7.88)$ & $(7.92)$ & $(7.09)$ & $(7.96)$ & $(7.93)$ \\
\hline \multirow[t]{2}{*}{$\begin{array}{l}\text { Population } \\
\text { (thousands) }\end{array}$} & -0.17 & -0.15 & -8.37 & 0.98 & -0.23 \\
\hline & $(0.26)$ & $(0.26)$ & $(7.20)$ & $(0.71)$ & $(1.22)$ \\
\hline \multirow[t]{2}{*}{$\begin{array}{l}\text { Elevation } \\
\text { (thousand meters) }\end{array}$} & -27.8 & $-34.9^{*}$ & -23.9 & -29.0 & -27.6 \\
\hline & $(18.5)$ & (19.5) & $(18.5)$ & $(18.5)$ & (18.1) \\
\hline \multirow[t]{2}{*}{ Catholic Center } & -4.35 & -9.24 & -278.4 & 71.7 & -7.98 \\
\hline & $(85.7)$ & $(82.4)$ & $(294.0)$ & $(93.3)$ & (111.5) \\
\hline \multirow[t]{2}{*}{ Competition } & & 49.9 & & & \\
\hline & & $(34.0)$ & & & \\
\hline \multirow[t]{2}{*}{$\begin{array}{l}\text { Executed by the } \\
\text { Left }\end{array}$} & & & 2.36 & & \\
\hline & & & $(2.08)$ & & \\
\hline \multirow[t]{2}{*}{ Clergy killed } & & & & -1.89 & \\
\hline & & & & $(1.16)$ & \\
\hline \multirow[t]{2}{*}{ Total Bombs } & & & & & 0.21 \\
\hline & & & & & $(3.77)$ \\
\hline \multirow[t]{2}{*}{ Constant } & $-34.6^{* *}$ & -26.3 & $-39.5^{* *}$ & $-32.5^{*}$ & $-34.5^{* *}$ \\
\hline & $(17.6)$ & $(36.5)$ & $(18.3)$ & $(17.6)$ & $(17.5)$ \\
\hline \multicolumn{6}{|l|}{ rho } \\
\hline \multirow[t]{2}{*}{ Constant } & $0.87^{\text {**** }}$ & $0.87^{* * *}$ & $0.85^{* * *}$ & $0.86^{* * *}$ & $0.87^{* * *}$ \\
\hline & $(0.13)$ & $(0.12)$ & $(0.14)$ & $(0.13)$ & $(0.13)$ \\
\hline \multicolumn{6}{|l|}{ sigma } \\
\hline \multirow[t]{2}{*}{ Constant } & $160.1^{* * * *}$ & $160.7^{* * *}$ & $157.5^{* * *}$ & $159.8^{* * * *}$ & $160.1^{* * *}$ \\
\hline & (19.2) & (19.3) & $(16.7)$ & $(19.1)$ & (19.2) \\
\hline Observations & 654 & 654 & 654 & 654 & 654 \\
\hline
\end{tabular}

Standard errors in parentheses ${ }^{*} p<0.10,{ }^{* *} p<0.05,{ }^{* * *} p<0.01$ 
Table 2. Spatial Error Regression for 1939 Displaced in Catalonia

\begin{tabular}{|c|c|c|c|c|c|}
\hline 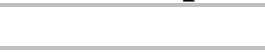 & M1 & M2 & M3 & M4 & M5 \\
\hline \multirow[t]{2}{*}{ Support_left36 } & $0.94^{* * * *}$ & & $0.98^{* * *}$ & $0.93^{* * *}$ & $0.94^{* * * *}$ \\
\hline & $(0.29)$ & & $(0.30)$ & $(0.29)$ & $(0.28)$ \\
\hline \multirow[t]{2}{*}{ CNT Affiliation } & $13.3^{* * * *}$ & $13.3^{* * *}$ & $12.7^{* * * *}$ & $13.7^{* * * *}$ & $13.3^{* * *}$ \\
\hline & $(3.87)$ & $(3.93)$ & $(3.38)$ & $(3.93)$ & $(3.87)$ \\
\hline \multirow[t]{2}{*}{ UGT Affiliation } & 0.042 & 0.29 & -1.76 & 0.40 & -0.011 \\
\hline & $(7.97)$ & $(7.99)$ & $(7.20)$ & $(8.05)$ & $(7.99)$ \\
\hline \multirow[t]{2}{*}{$\begin{array}{l}\text { Population } \\
\text { (thousands) }\end{array}$} & -0.14 & -0.12 & -8.10 & 1.04 & -0.20 \\
\hline & $(0.26)$ & $(0.26)$ & $(7.23)$ & $(0.70)$ & $(1.21)$ \\
\hline \multirow[t]{2}{*}{$\begin{array}{l}\text { Elevation } \\
\text { (thousand meters) }\end{array}$} & $-43.0^{*}$ & $-50.7^{* * *}$ & -38.7 & $-44.3^{*}$ & $-42.9^{*}$ \\
\hline & $(24.4)$ & $(25.2)$ & (24.4) & $(24.3)$ & $(23.9)$ \\
\hline \multirow[t]{2}{*}{ Catholic Center } & -10.9 & -15.2 & -276.8 & 67.0 & -14.4 \\
\hline & $(85.9)$ & $(82.6)$ & $(294.4)$ & $(93.2)$ & $(112.0)$ \\
\hline \multirow[t]{2}{*}{ Competition } & & 51.4 & & & \\
\hline & & $(33.2)$ & & & \\
\hline \multirow[t]{2}{*}{$\begin{array}{l}\text { Executed by the } \\
\text { Left }\end{array}$} & & & 2.29 & & \\
\hline & & & $(2.09)$ & & \\
\hline \multirow[t]{2}{*}{ Clergy killed } & & & & $-1.94^{*}$ & \\
\hline & & & & $(1.15)$ & \\
\hline \multirow[t]{2}{*}{ Total bombs } & & & & & 0.21 \\
\hline & & & & & $(3.77)$ \\
\hline \multirow[t]{2}{*}{ Constant } & 77.0 & 90.5 & 66.5 & 78.3 & 77.1 \\
\hline & $(57.5)$ & $(74.4)$ & $(49.9)$ & $(56.9)$ & $(57.7)$ \\
\hline \multicolumn{6}{|l|}{ lambda } \\
\hline \multirow[t]{2}{*}{ Constant } & $0.87^{* * * *}$ & $0.88^{* * * *}$ & $0.86^{* * *}$ & $0.87^{* * *}$ & $0.87^{* * *}$ \\
\hline & $(0.12)$ & $(0.11)$ & $(0.14)$ & $(0.13)$ & $(0.12)$ \\
\hline \multicolumn{6}{|l|}{ sigma } \\
\hline \multirow[t]{2}{*}{ Constant } & $160.1^{* * *}$ & $160.6^{* * *}$ & $157.7^{* * *}$ & $159.8^{* * *}$ & $160.1^{* * *}$ \\
\hline & $(19.2)$ & $(19.4)$ & $(16.8)$ & $(19.2)$ & $(19.3)$ \\
\hline Observations & 654 & 654 & 654 & 654 & 654 \\
\hline
\end{tabular}

Standard errors in parentheses

${ }^{*} p<0.10,{ }^{* *} p<0.05,{ }^{* * *} p<0.01$

Table 1 displays the results of the spatial lag regressions on 1939 Displacement; Table 2 displays the results of the spatial error models. They are both consistent and supportive of our main hypothesis: Support Left 1936 has a positive impact on displacement in all the models. In other words, the number of displaced people leaving a locality increases with support to the leftist bloc in the prewar elections. Specifically, a 10 points increase in vote for the left is associated with an average increase of 9 individuals in the number of displaced in a locality. 
In both spatial regression models, CNT affiliation also has a very significant impact on levels of displacement, which implies that places with an anarchist presence observed higher displacement; this is also consistent with our hypothesis because CNT affiliates were leftists. In addition to collective targeting, there is an alternative mechanism that might account for this: places with CNT affiliation observed high levels of violence against right-wing supporters in the previous period, and many militants and their families left out of fear of reprisals as the frontline began to shift. UGT affiliation is not significant, and neither is Catholic Center, which proxies for right-wing support. This is unexpected, as these variables proxy presence of left and right wing supporters; yet, Support Left might be already capturing their effect. Elevation is negative and significant in some of the models (indicating that displacement was greater in lower places). Neither Competition nor Executed by the Left are significant. Clergy Killed has only a significant effect in the spatial error model, indicating that places where there was anti-clerical violence had less displacement, which is counterintuitive, as we would expect the perpetrators of this violence to flee out of fear of reprisals. Finally, total number of bombings in a locality does not have a positive impact on displacement, contrary to our expectations. This might be because bombings generated temporary refugees, who returned to their homes once the bombings ended.

The results in Tables 1 and 2 are robust to differently specified dependent variable (e.g. absent people in the locality, percentage of displaced population in the locality) and to nonspatial regression models (e.g. OLS, negative binomial). Also, we run robustness checks with imputed displacement data for Catalonia, which allows us to work with 1,052 cases, and the results are consistent. Finally, we generate a dummy for municipalities where the left obtained more than $50 \%$ of the vote and match the municipalities on the main covariates in the regressions above (using nearest neighbor matching), as well as on Latitude, Longitude and Percent Literate 
in the locality. The Average Treatment Effect for the Treated (ATT) is 34, which shows that being a municipality with a majority of support for the left (the treatment in this case) has a very significant and positive effect on number of individuals displaced (leading to 34 more individuals displaced, on average). The results of the matching estimators are included in the Appendix. $^{14}$

\section{$\underline{\text { Colombia }}$}

In Colombia, the Catholic Church and the Bogotá-based NGO CODHES (Consultancy for Human Rights and Displacement) have documented displacement since the mid-1980s. The state began registering internally displaced people (IDPs) about a decade later, in $1998 .{ }^{15}$ The registry, known as SUR, the Sistema Único de Registro, contains 2,169,874 registrations between 1998 and June 2007. ${ }^{16}$ CODHES, which approximates the arrival of IDPs to municipalities based on its local contacts, estimates that between 1986 and 2007, over 3.8 million people were displaced. Figure A1 of the Appendix compares the scale of displacement as registered by the government and CODHES between 1998 and 2006.

To test our hypothesis in Colombia, we compare local electoral results for the UP during the 1990s across municipalities with displacement in those municipalities in subsequent years. The cross-sectional dataset includes 1,056 observations - for each municipality in Colombia that existed in 1998. The data on displacement come from the SUR. ${ }^{17}$ Each registration includes the municipality of origin and resettlement. ${ }^{18}$ We use the database put together by Steele (2010), who aggregates the individual-level SUR displacement registrations by municipality of origin between 1998 and 2006 to create IDPs. Figure 3 shows the municipal-level variation across the country, including pre-1998, retroactive IDP registrations back to 1990. 
Figure 3. Displacement from Municipalities in Colombia, 1990-2006

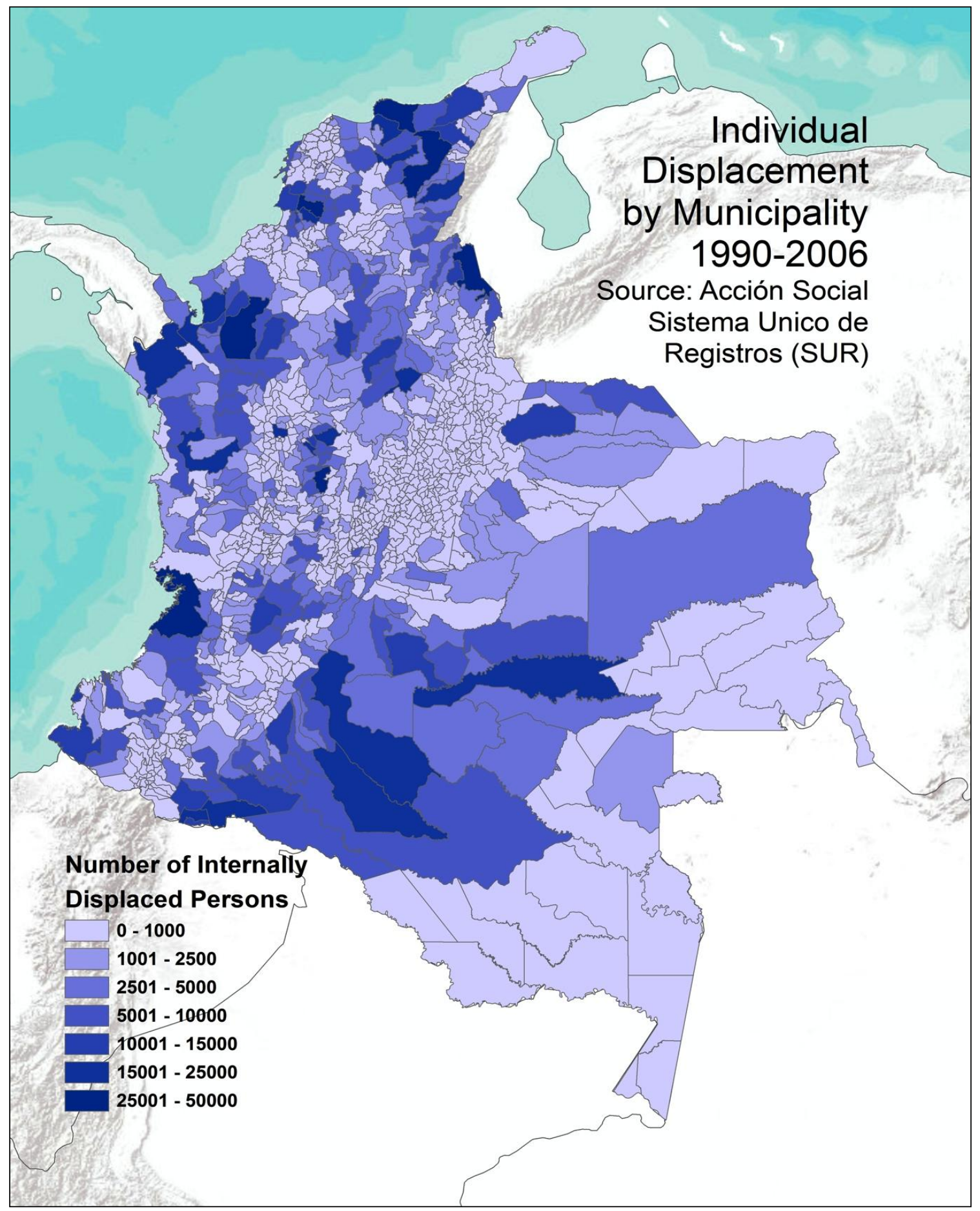

Although the data on the displaced in Colombia are among the best in the world, one 
concern with using observational data such as these is that biases may be systematic over time, or across space. While the Colombian Supreme Court found the SUR does not adequately count all of the displaced, a study has found that under-counting appears to be unsystematic (Ibáñez, \& Velásquez, 2006). The data represent a vast improvement over data available at the crossnational level.

To measure perceived disloyalty in Colombia, we use the local-level electoral share for Unión Patriótica (UP). Concejos, or councils, manage the affairs of municipalities as the local legislative body. The local electoral outcomes are accurate indicators of our primary independent variable, and have the added advantage of being systematically collected across the country. ${ }^{19}$ UP Vote Share: To indicate the presence of UP supporters, we take the average UP vote share from the 1990, 1992, 1994 and 1997 elections, by municipality. We also use an alternative indicator - a dummy variable equal to 1 if the UP won votes in any of these elections (UP Dummy). The UP won some percentage of the council vote in 205 municipalities, and won at least one seat in 141 . In other words, the party established some kind of presence in roughly $20 \%$ of the municipalities of the country, but had actual political representation at the local level in about $15 \%$ of the country. The average UP vote share across all municipalities is $1 \%$.

Another political variable we include, Third Party Vote Share, is the average third party vote share between 1990 and 1997 - a variable similar to the indicator that Acemoglu, et al. (2013) employ to proxy for paramilitary presence. ${ }^{20}$ We constructed the variable by taking the average vote share for all non-traditional, non-leftist, non-Christian parties for concejo elections, based on the same data from the Registraduría Nacional used to calculate the UP vote share. We expect displacement to be negatively associated with this variable, because in this period, paramilitaries were expanding and would not target their own supporters. A final variable we 
include to indicate leftist presence is Strikes: the total number of labor strikes between 1982 and 1997 in the municipality. These data were collected by CINEP, a Bogotá-based NGO.

As we did for Spain, we include a series of controls that may have an impact on the levels of displacement across Colombia: Elevation, in meters (CEDE) to control for accessibility of the location; municipal population in 1993 (1993 Population), based on the census (obtained from the Departamento Administrativo Nacional de Estadística DANE; National Administrative Department of Statistics), to control for size. ${ }^{21}$

We also include data on violence by each of the groups: ${ }^{22}$ Paramilitary Victims is the aggregate of victims of lethal violence attributed to paramilitary groups by municipality between 1998 and 2006; FARC Victims is the same, but for those victims attributed to the FARC (Departamento Administrativo de Seguridad (Administrative Department of Security - DAS). ${ }^{23}$

Figure 4 shows the bivariate relationship between the average share of votes that the UP won in four local elections between 1990 and 1997 and the total number of individuals displaced from a municipality between 1998 and 2006. The graph displays a positive and linear relationship, consistent with our hypothesis, and it is consistent with Figure 2, which depicted a similar relationship in Catalonia. 
Figure 4. UP Average \% Vote Share in Local Elections, 1990-1997 and Cumulative IDPs, 1998-2006

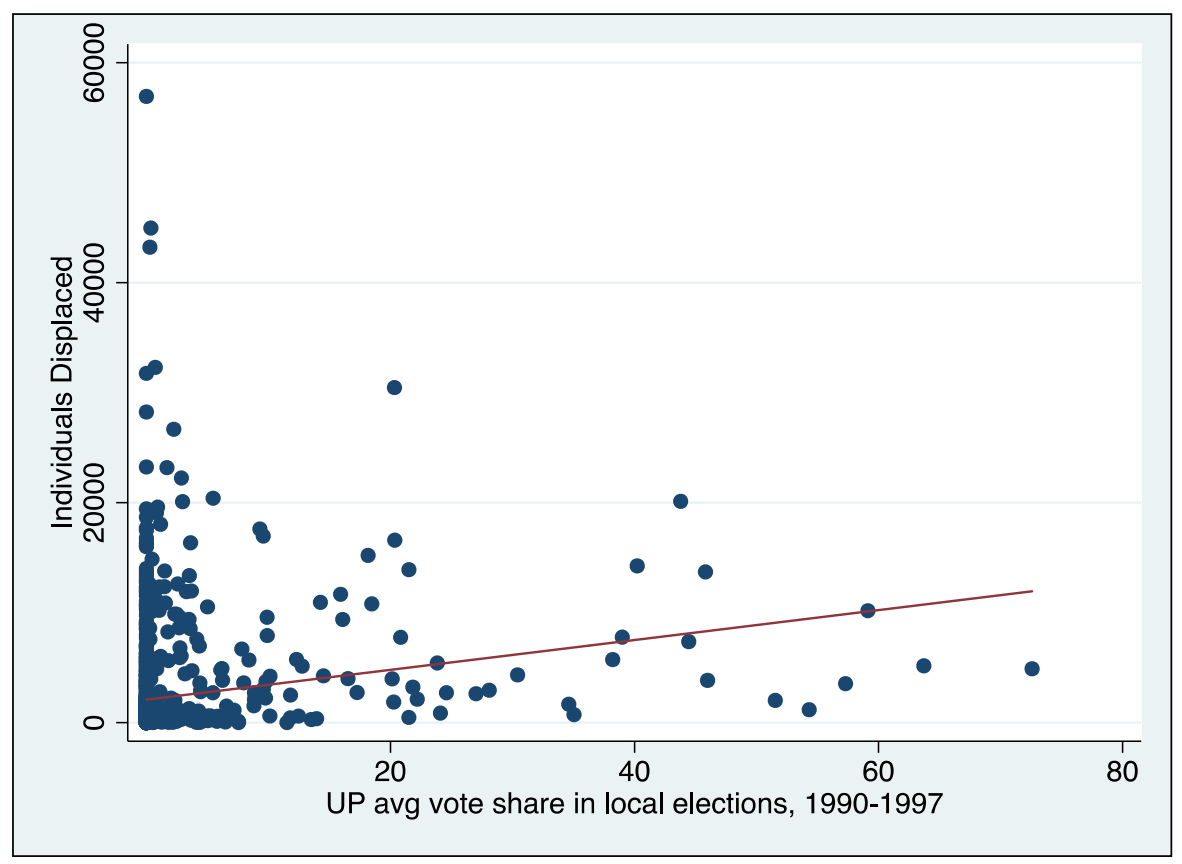

We check for spatial autocorrelation in our dependent variable and the I-Moran's statistic $(0.061$, significant at the $99 \%$ level -both in one-tail and two-tail tests) indicates that there is significant spatial autocorrelation in the data. Like we did with the Spanish data, we run spatial regression models to test our hypothesis. Table 3, which is an approximation of Table 1, shows the results of the spatial lag regression in Colombia, and it shows that UP vote share has a positive and significant effect on the level of displacement from a municipality. The results of the spatial error model (Table 5) are also consistent. Model 1 indicates that an increase in one percentage point in average support for UP candidates between 1990 and 1997 corresponds to an increase in over 9,000 additional displaced individuals between 1998 and 2006. The effect is thus quite substantial. 
Table 3. Spatial Lag Regression. Colombia (IDPs 1998-2006)

\begin{tabular}{|c|c|c|c|c|c|}
\hline & M1 & M2 & M3 & M4 & M5 \\
\hline \multirow[t]{2}{*}{$\begin{array}{l}\text { UP vote share avg } \\
90-97\end{array}$} & $9170.1^{* * *}$ & & & $9984.8^{\text {**** }}$ & $5935.7^{* * *}$ \\
\hline & $(1795.2)$ & & & $(2130.0)$ & $(1887.1)$ \\
\hline \multirow[t]{2}{*}{$\begin{array}{l}\text { Total paramilitary } \\
\text { victims 1998-2006 }\end{array}$} & $4.91^{* * *}$ & $5.00^{* * *}$ & & & $2.47^{* *}$ \\
\hline & $(0.78)$ & $(0.80)$ & & & $(0.98)$ \\
\hline \multirow[t]{2}{*}{$\begin{array}{l}\text { Total labor strikes, } \\
\text { 1982-1997 }\end{array}$} & 117.7 & 121.5 & $184.9^{*}$ & $179.6^{*}$ & $134.8^{*}$ \\
\hline & $(93.5)$ & $(93.4)$ & (100.6) & $(100.4)$ & $(79.2)$ \\
\hline \multirow[t]{2}{*}{$\begin{array}{l}1993 \text { population } \\
\text { (thousands) }\end{array}$} & -4.14 & -4.37 & -6.25 & -5.96 & -5.61 \\
\hline & $(4.08)$ & $(4.05)$ & $(4.47)$ & $(4.50)$ & $(3.48)$ \\
\hline \multirow[t]{2}{*}{ Elevation (meters) } & $-0.35^{* *}$ & $-0.42^{* * *}$ & $-0.53^{* * *}$ & $-0.46^{* * *}$ & $-0.34^{* * *}$ \\
\hline & $(0.14)$ & $(0.15)$ & $(0.19)$ & $(0.17)$ & $(0.13)$ \\
\hline \multirow[t]{2}{*}{$\begin{array}{l}\text { 3rd party vote share } \\
\text { avg } 90-97\end{array}$} & $1301.8^{* *}$ & $1645.9^{* * *}$ & $1986.0^{* * * *}$ & $1605.0^{* * *}$ & \\
\hline & $(528.5)$ & $(559.9)$ & $(746.8)$ & (735.6) & \\
\hline \multirow[t]{2}{*}{$\begin{array}{l}\text { Total FARC victims } \\
\text { 1998-2006 }\end{array}$} & & & & & $1.07^{* * *}$ \\
\hline & & & & & $(0.28)$ \\
\hline \multirow[t]{2}{*}{ _cons } & -29.1 & 140.0 & $536.5^{*}$ & 346.2 & 65.2 \\
\hline & $(258.4)$ & $(269.4)$ & $(318.7)$ & $(302.1)$ & $(231.0)$ \\
\hline \multicolumn{6}{|l|}{ rho } \\
\hline \multirow[t]{2}{*}{ _cons } & $0.92^{* * *}$ & $0.92^{* * * *}$ & $0.91^{* * * *}$ & $0.91^{* * *}$ & $0.93^{* * *}$ \\
\hline & $(0.051)$ & $(0.050)$ & $(0.059)$ & $(0.060)$ & $(0.047)$ \\
\hline \multicolumn{6}{|l|}{ sigma } \\
\hline \multirow[t]{2}{*}{ _cons } & $3648.3^{* * *}$ & $3712.6^{* * * *}$ & $4030.1^{* * *}$ & $3959.8^{* * * *}$ & $3258.4^{* * * *}$ \\
\hline & $(406.9)$ & $(397.5)$ & $(404.3)$ & (411.7) & (387.4) \\
\hline Observations & 1123 & 1123 & 1123 & 1123 & 1123 \\
\hline
\end{tabular}

Standard errors in parentheses

${ }^{*} p<0.10,{ }^{* *} p<0.05,{ }^{* * *} p<0.01$ 
Table 4. Spatial Error Colombia. (IDPs 1998-2006)

\begin{tabular}{|c|c|c|c|c|c|}
\hline & M1 & M2 & M3 & M4 & M5 \\
\hline \multirow[t]{2}{*}{$\begin{array}{l}\text { UP vote share } \\
\text { avg } 90-97\end{array}$} & $9074.6^{* * *}$ & & & $9910.3^{* * *}$ & $6140.2^{* * *}$ \\
\hline & (1817.5) & & & (2181.6) & (1884.4) \\
\hline \multirow[t]{2}{*}{$\begin{array}{l}\text { Total } \\
\text { paramilitary } \\
\text { victims 1998- } \\
2006\end{array}$} & $4.94^{* * *}$ & $5.03^{* * *}$ & & & $2.48^{* *}$ \\
\hline & $(0.79)$ & $(0.81)$ & & & $(0.99)$ \\
\hline \multirow{2}{*}{$\begin{array}{l}\text { Total labor } \\
\text { strikes, 1982- } \\
1997\end{array}$} & 118.9 & 123.4 & $184.7^{*}$ & $178.7^{*}$ & $133.1^{*}$ \\
\hline & (93.1) & (93.0) & $(100.0)$ & $(100.0)$ & (79.1) \\
\hline \multirow[t]{2}{*}{$\begin{array}{l}1993 \text { population } \\
(* 1000)\end{array}$} & -4.16 & -4.41 & -6.18 & -5.87 & -5.51 \\
\hline & $(4.08)$ & $(4.05)$ & $(4.48)$ & $(4.51)$ & $(3.49)$ \\
\hline \multirow[t]{2}{*}{ Elevation } & $-0.37^{* *}$ & $-0.43^{* * *}$ & $-0.56^{* *}$ & $-0.49^{* *}$ & $-0.35^{* *}$ \\
\hline & $(0.18)$ & $(0.20)$ & $(0.26)$ & $(0.23)$ & $(0.17)$ \\
\hline \multirow[t]{2}{*}{$\begin{array}{l}\text { 3rd party vote } \\
\text { share avg 90-97 }\end{array}$} & $1107.6^{* *}$ & $1388.0^{* *}$ & $1843.0^{* *}$ & $1527.5^{* *}$ & \\
\hline & (555.9) & $(583.5)$ & $(788.5)$ & $(779.2)$ & \\
\hline \multirow[t]{2}{*}{$\begin{array}{l}\text { Total FARC } \\
\text { victims 1998- } \\
2006\end{array}$} & & & & & $1.06^{* * *}$ \\
\hline & & & & & $(0.29)$ \\
\hline \multirow[t]{2}{*}{ Constant } & $4013.6^{*}$ & $4739.7^{*}$ & $5034.7^{*}$ & $4292.7^{*}$ & $3664.0^{*}$ \\
\hline & $(2310.6)$ & $(2690.6)$ & $(2581.7)$ & $(2202.5)$ & (1965.8) \\
\hline \multicolumn{6}{|l|}{ lambda } \\
\hline \multirow[t]{2}{*}{ _cons } & $0.93^{* * *}$ & $0.93^{* * *}$ & $0.92^{* * *}$ & $0.92^{* * *}$ & $0.93^{* * *}$ \\
\hline & $(0.048)$ & $(0.046)$ & $(0.053)$ & $(0.055)$ & $(0.048)$ \\
\hline \multicolumn{6}{|l|}{ sigma } \\
\hline \multirow[t]{2}{*}{ _cons } & $3661.5^{* * *}$ & $3720.7^{* * *}$ & $4035.1^{* * *}$ & $3969.9^{* * *}$ & $3285.2^{* * *}$ \\
\hline & $(408.7)$ & $(400.5)$ & $(408.4)$ & $(414.5)$ & (388.4) \\
\hline Observations & 1123 & 1123 & 1123 & 1123 & 1123 \\
\hline
\end{tabular}

Several other variables in the model are also significant. The only one that is as substantively comparable to UP vote share is the average third party vote share. Surprisingly, the effect is also positive. We expected that communities with high third party vote share would be more likely to support paramilitaries (or to be areas that the paramilitaries already control). As such, residents there would be less likely to be displaced; however, it is plausible that insurgents retaliated 
against paramilitary incursion during the second period (1998-2006). This finding needs further investigation. Paramilitary violence - proxied by the total number of victims between 1998 and 2006 - is positively correlated with displacement. Yet, it has a much smaller effect than UP vote share. Total labor strikes between 1982 and 1997, an additional indicator for leftist presence, also has a positive effect on displacement, though it falls short of statistical significance in Models 1 and 2.

Table 4 shows the results from a spatial error model, which are consistent with the findings in Table 3. The findings are robust to different specifications and additional control variables (see Tables A3-A5 in the Appendix). In addition, we also match our data (like we did for Catalonia, using nearest neighbors matching) and estimate for the effect of a UP "treatment", which in this case measures all the localities with UP presence. The results show that UP municipalities suffer much more displacement than others. The ATT is 1,577 , which indicates that municipalities with UP presence have on average 1,577 more individuals displaced than those municipalities without UP presence. All of the above constitutes strong evidence in favor of the hypothesis that UP municipalities seem to have been specifically targeted for displacement by the paramilitaries.

\section{DISCUSSION}

The quantitative evidence above is supportive of our hypothesis: in both Colombia and Spain, we find that displacement is more prevalent in localities where a rival's political base exists and is revealed in elections. In the case of Spain, we have observed that the number of displaced at the local level when the right enters the localities (in 1939) increases with the proportion of support for the left in the 1936 elections -and thus, with the number of left-wing supporters. This is consistent with our microfoundations: leftists were collectively targeted by the Francoists, and 
thus they were more likely to leave as the Francoist army was conquering the territory. Not all those people who voted for the left in the 1936 elections fled, but those who were more strongly identified with the left-wing political parties and trade unions did: for example, displacement was highest in places where an anarchist trade union was present before the war. In Colombia, we also observe that displacement is positively associated with support for the UP -the political party associated with the FARC.

There are important differences between the two cases: in Colombia, the proportion of displaced over the population was higher than in Catalonia (6.8\% vis-à-vis $2.4 \%)$; in Catalonia, the average vote share for the left was about $53 \%$, while the vote share for the UP in Colombia was around $6 \%$. But displacement seems to be following the same logic. Indeed, the political variables are highly significant in both cases, controlling for the available indicators on economic inequality, wartime violence, urbanization and geographical location. If displacement were simply a by-product of two warring parties, or an unintended consequence of lethal violence, political factors would not be statistically significant, and they would not be as robust as they are in our analyses, across both cases.

\section{$\underline{\text { Mechanisms }}$}

In this subsection, we present qualitative evidence that illustrates that collective targeting against civilians by armed groups led to displacement in these two civil wars. In addition, we discuss and discard alternative possibilities. In Spain, both sides targeted groups that were suspected of disloyalty, but this was particularly salient in conquest phases, such as during the conquest of Catalonia by the Francoist army, which we have explored above. In other areas of Spain displacement also took place as armed groups were conquering new territory. Displacement was simultaneous to terrorizing campaigns of violence, which often accompanied conquest by the 
Francoist army (Preston, 2011:19). That was the case, for example, of the Nationalist "Death column" that conquered Andalusia and Extremadura: this military column made widespread use of collective violence against alleged leftists, which was public in many occasions (i.e. leaving the corpses in the open for the neighbors to collect). After this violence "many people opted to leave towards Republican territory, hide in the mountains, or hide in the most unbelievable places" (Prada, 2010: 120). The people fleeing were sympathizers and/or militants of leftist political parties: in other words, those targeted by the Nationalists (Preston, 2011: 412). In the mountainous county of the Pallars Sobirà, when the frontline stabilized near the town of Sort, the Francoist general Sagardía employed collective targeting in order to "cleanse" the area from leftist supporters, who were perceived as extremely unreliable in this rough terrain area, in which the Republicans employed guerrilla tactics. The general sent three police troops to the villages in order to pursue tasks of vigilancia y limpieza (surveillance and cleansing), and he argued that suspicious inhabitants of the villages had to be evacuated. ${ }^{24} \mathrm{~A}$ civil war testimony from this county told one of the authors that "When the Francoists arrived, militants of left-wing parties left because they were scared". ${ }^{25}$

Collective violence was also employed by leftists in the Spanish Civil War. Even if on a smaller scale, the anarchists and socialists were also targeting collectively in phases of conquest. In localities close to the Ebro's frontline (in Aragon), which were contested between the Francoists and anarchist and communist columns for several months, suspected right-wingers were threatened and killed. Many of those who feared for their lives because they did not share the views of the anarchists (including sympathizers of the moderate left) fled towards Catalonia, Nationalist Aragon, or France (Ledesma, 2003; Maldonado, 2007). In Madrid, the targeting of suspected Francoist supporters intensified after the fall of Toledo and the frontline moved 
towards Madrid. Collective targeting boosted as the fear of the existence of a fifth column within Madrid and the need to expel Francoist supporters became more salient (Ruiz, 2012: 233-235).

In Colombia, the descriptions of displacement beginning in 1986 - only after the UP was formed - linked it to paramilitaries and narcotraffickers targeting the UP and those accused of being collaborators of the guerrilla (Pastoral Social, 2001: 15). A brutal example took place in the municipality of Segovia in 1988. A group of paramilitaries arrived in Segovia where "names of people were replaced by names of blocks" that displayed yellow and green banners - the colors of the UP (Dudley 2006: 123-124). Pamphlets were circulated, warning citizens to leave or die. The violence was targeted to known areas where UP sympathizers gathered or lived: paramilitaries lobbed grenades and opened fire. In all, 43 people were killed (Dudley 2006: 124). The key is that pamphlets were circulated, which indicates that the aim was not to kill all inhabitants of the neighborhood, but to expel them. Steele (2011) also finds that paramilitaries cleansed the city of Apartadó between 1994 and 1996, using lethal violence and tactics like graffiti to compel residents of UP-associated neighborhoods to leave. Paraphrasing Mao’s famous dictum, a priest from the region said that paramilitaries' strategy at the time was "to push the guerrillas into the mountains...to repel them so they would lose contact with the people, and lose their power. To carry out their strategy, the tactic they used was the perverse one of draining the water from the fish. A barbarous method."26

Regarding the alternative hypotheses, the first possibility is that people flee in anticipation of the violence, and that armed groups do not in fact use collective targeting to provoke flight. However, instances of pamphlets warning residents to leave targeted neighborhoods and towns abound. Why would armed groups distribute such threats if they did not aim to expel suspect groups? The second alternative is that in fact armed groups are targeting 
their rival armed group, not the civilians who live in these territories. This alternative is a possibility for irregular civil wars, but not for conventional ones, in which soldiers are distinct from civilians. Thus collective violence in locations with no military garrisons is aimed at targeting civilians. In irregular wars, some people do become "part-time" combatants and remain in their neighborhoods and villages, and some combatants do hide among civilians. These insurgents could be targeted by incoming challengers that do not aim to displace the civilians they live among. However, such a form of targeting would be likely to be accompanied by overtures to the civilians to remain in their homes in spite of the violence directed at the combatants. However, in the case of Colombia, we have not found any evidence that armed groups seek to expel combatants but retain civilians - the pamphlets and graffiti used were directed against UP members - not the FARC only.

\section{$\underline{\text { Implications }}$}

We presented evidence that armed groups employ displacement under similar circumstances across very different civil wars. Nonetheless, given the diverging characteristics of civil wars displaying different technologies of rebellion, we expect the underlying logic to produce different aggregate patterns. We briefly consider the implications in conventional and irregular civil wars for two dimensions: timing and scale of displacement.

With regards to the timing, we argue that displacement is associated with the conquest of territories; in conventional wars, displacement is likely to be concentrated in waves, following phases of conquest in which the frontline moves. In irregular wars, when loyalties are identified, displacement is likely to occur in a more uneven, sporadic way throughout the war. In Spain, we do indeed observe waves of displacement that were connected to conquest. For example, in 
Catalonia, there were two main phases of displacement: the so-called Exile of 1936 affected mostly people identified with right-wing political parties, landlords and members of the bourgeoisie, members of the clergy, and even people identified with left-wing political parties that were threatened by the anarchist militias. This took place early on in the war, until the frontlines were established. The second phase was the so-called Exile of 1939, which we have analyzed above, and which affected mostly people who identified as supporters of leftist political parties or trade unions. ${ }^{27}$ This wave of displacement corresponds to the moment in which the frontline was moving and the Nationalist army was conquering Catalonia. Historical accounts overwhelmingly indicate that these people were moving towards the North, as the frontline was advancing and the Republican army was withdrawing. In another paradigmatic case of a conventional civil war, the American one, refugees fled from battles and areas occupied by the Union army (Hacker 2011: 326).

In Colombia, displacement was not a major feature of the low-grade insurgency until the late 1980s. Once the UP contested local elections and its supporters revealed where they lived, displacement became a tactic that armed groups could employ to challenge insurgents for territorial control. As the counterinsurgent paramilitaries expanded, they displaced people who they perceived to be disloyal - and displacement continued to increase steadily over time and across space. Because of the nature of contestation in irregular war, displacement took place in a scattered way throughout the Colombian territory, wherever UP supporters were. ${ }^{28}$

The scale of displacement in both types of civil war depends, obviously, on how well identified the likely insurgent sympathizers are, and the proportion of the population they represent. Following our theoretical framework, the scale of displacement in conventional civil wars is also likely to depend on the amount of times the frontlines shift between actors - with 
each shift likely to lead to additional displacement. Similarly, the scale in irregular wars is likely to depend on how unstable territorial control is: the more stable the territorial control, the lower the displacement. Finally, given all this, since irregular civil wars are typically significantly longer than conventional ones, we can expect the former to generate an overall greater number of refugees. Indeed, though the Spanish civil war generated a large number of refugees, the Colombian war has significantly surpassed it (by a factor of 10), and this is partly due to the much longer duration of the latter.

Finally, this paper also has implications for the distinction between ethnic and non-ethnic civil wars, which are often assumed to feature different dynamics of violence and displacement (Kaufmann, 1996). As authors such as Kalyvas (2006), Christia (2012), and Lyall (2010) have shown, wartime dynamics do not necessarily follow ethnic lines, even in wars labeled as "ethnic." Furthermore, dynamics of lethal violence in ideological civil wars are not different from those in ethnic civil wars (Balcells 2016). By providing evidence on displacement from two ideological civil wars that follow similar patterns and resemble the goals and tactics of ethnic cleansing, we find additional support for the claim that ethnic cleansing is one type of a broader category: political cleansing.

\section{CONCLUSIONS}

The paper makes several contributions. First, it shows that the logic of displacement is indeed similar across types of civil wars. Even in non-ethnic civil wars, armed groups employ "cleansing" against civilians. An important area for further research is on varieties of displacement in ethnic and non-ethnic civil wars in addition to cleansing, to continue to identify overlaps and divergence between them. Second, the mechanisms underlying collective targeting 
and displacement are consistent across civil wars with different forms of warfare or "Technologies of Rebellion", in contrast to the evidence on lethal violence. Third, it highlights the risks of electoral politics preceding or during a civil war: they may reveal political identities that are integral to competing armed groups in the war. Fourth, this paper is the first small-n comparison of displacement at the sub-national level. Our design has the advantage of comparing two very different cases that display similar outcomes; following Mill's method of difference, this should provide generalizability. At the same time, the two-case comparison allows us to connect micro-level processes to macro-level ones; indeed, the paper has advanced the understanding of displacement at the macro-level from a micro-level framework (Balcells \& Justino, 2014). Specifically, the nature of warfare shapes the conditions under which displacement is used as a war tactic. Thus, our approach has clear implications concerning why displacement is more prevalent in some wars than in others, and why displacement is spread throughout conflict areas and time periods in some wars (i.e. irregular, as in Colombia, El Salvador or the current conflict in Afghanistan), and more concentrated in areas and time periods in other wars (i.e. conventional, as in the recent wars in Ivory Coast or Libya). These insights shed light on broad patterns of displacement in civil wars. 


\section{References}

Acemoglu, D., Robinson, J. \& Santos, R. (2013). The Monopoly of Violence: Evidence from Colombia. Journal of the European Economic Association, 11, 5-44.

Adhikari, P. (2012). Conflict-Induced Displacement: Understanding the Causes of Flight. American Journal of Political Science, 57, 82-89.

Armengou, M, \& Belis, R. (2004). Les Fosses del Silenci: Hi ha un Holocaust Espanyol? Barcelona: Televisió de Catalunya \& Rosa dels Vents.

Azam, J.P., \& Hoeffler, A. (2002). Violence against Civilians in Civil Wars: Looting or Terror? Journal of Peace Research, 39, 461-485.

Balcells, L. (2010). Rivalry and Revenge. Violence against Civilians in Conventional Civil Wars, International Studies Quarterly, 54, 291-313.

Balcells, L. (2016). Rivalry and Revenge: The Politics of Violence in Civil War. Cambridge University Press (In Press). 
Balcells, L., \& Justino, P. (2014). Bridging Micro and Macro Approaches on Civil Wars and Political Violence: Issues, Challenges, and the Way Forward Journal of Conflict Resolution, 58, 1343-1359.

Bulutgil, H.Z. (2009). Territorial Conflict and Ethnic Cleansing. Ph.D. diss., University of Chicago.

Bulutgil, H. Z. (2015). Social Cleavages, Wartime Experience, and Ethnic Cleansing in Europe. Journal of Peace Research, 52, 577-590.

Centro Nacional de Memoria Histórica. (2012). Basta Ya: Colombia: Memorias de Guerra y Dignidad, http://www.centrodememoriahistorica.gov.co/micrositios/informeGeneral/. Accessed 18 September 2015.

Cepeda Castro, I. (2006). Genocidio Político: El Caso de la Unión Patriótica en Colombia. Revista Cejil, 1, 101-112.

Christia, F. (2012). Alliance Formation in Civil Wars. Cambridge: Cambridge University Press.

Confederación Nacional del Trabajo (CNT). (1936). El Congreso Confederal de Zaragoza. Solidaridad Obrera, May issue. 
Cucó Giner, A. (1970). Contribución a un Estudio Cuantitativo de la C.N.T, Saitabi, 20, 181-202.

Davenport, C., Moore, W.H., \& Poe, S.C. (2003). Sometimes You Just Have to Leave: Domestic Threats and Refugee Movements, 1964-1989, International Interactions, 29, 27-55.

Dudley, S. S. (2006). Walking Ghosts: Murder and Guerrilla Politics in Colombia, New York:

Routledge.

Echandía, C. (2006). Dos Decadas del Conflict Interno en Colombia: 1986-2006. Bogotá:

Universidad del Externado.

Fjelde, H. \& Hultman, L. (2014). Weakening the Enemy A Disaggregated Study of Violence against Civilians in Africa. Journal of Conflict Resolution, 58, 1230-1257.

Gil, F. \& Garcia, A. (2009). La Mortalidad en la Infancia Durante la Guerra Civil: Impacto Territorial Estimado a Partir del Censo de 1940. Revista Española de Investigaciones Sociológicas, 127, 55-91.

Giraldo, F. (2001). Democracia y Discurso Político en la Unión Patriótica. Bogotá: Centro Editorial Javeriano (CEJA). 
Hacker, J. D. (2011). A Census-Based Count of the Civil War Dead, Civil War History, 57, 307348.

Ibáñez, A.M. (2008). El Desplazamiento Forzoso en Colombia: Un Camino sin Retorno a la Pobreza. Bogotá: Universidad de los Andes.

Ibáñez, A. M. \& Velásquez, A. (2006). El Proceso de Identificación de Víctimas de los Conflictos Civiles: Una Evaluación para la Población Desplazada en Colombia. Documento CEDE.

Internal Displacement Monitoring Center (IDMC). (2014). http://www.internaldisplacement.org/americas/colombia/figures-analysis. Accessed 18 September 2015.

Kalyvas, S. N. (2006). The Logic of Violence in Civil War. Cambridge: Cambridge University Press.

Kalyvas, S. N., \& Balcells, L. (2010). International System and Technologies of Rebellion: How the Cold War Shaped Internal Conflict, American Political Science Review, 104, 415-429

Kalyvas, S. N., \& Kocher, M. (2007). How 'Free' is Free Riding in Civil Wars?: Violence, Insurgency, and the Collective Action Problem, World Politics, 59, 177-216. 
Kaufmann, C. (1996). Possible and Impossible Solutions to Ethnic Conflict, International Security, 20, 136-175.

Ledesma, J. L. (2003). Los Días de Llamas de la Revolución: Violencia y Política en la Retaguardia Republicana de Zaragoza Durante la Guerra Civil. Zaragoza: Institución "Fernando el Católico" (C.S.I.C).

López, C., (ed.). (2010). Y Refundaron la Patria: De Cómo Mafiosos y Políticos Reconfiguraron el Estado Colombiano. Bogotá: Debate.

Lozano-Garcia, N., Piras, G., Ibáñez, A.M., \& Hewings, G. (2010). The Journey to Safety: Conflict-Driven Migration Flows in Colombia, International Regional Science Review, $33,157-180$.

Lubkemann, S. B. (2008). Culture in Chaos: An Anthropology of the Social Condition in War. Chicago: University of Chicago Press.

Lyall, J. (2010). Are Co-Ethnics More Effective Counter-Insurgents? Evidence from the Second Chechen War. American Political Science Review, 104, 1-20. 
Maldonado, J. M. (2007). El Frente de Aragón: La Guerra Civil en Aragón (1936-1938).

Zaragoza: Mira Editores.

Marrus, M. R. (2002). The Unwanted: European Refugees from the First World War Through the Cold War. Philadelphia: Temple University Press.

Melander, E, \& M. Oberg. (2006). Time to go? Duration Dependence in Forced Migration. International Interactions, 32, 129-152.

Moore, W. H., \& Shellman, S. (2006). Refugee or Internally Displaced Person?: To Where Should One Flee? Comparative Political Studies, 39, 599-622.

Pastoral Social. (2001). Desplazamiento Forzado en Antioquia: Magdalena Medio. Bogotá: Conferencia Episcopal de Colombia.

Prada, J. (2010). La España Masacrada. Madrid: Alianza.

Preston, P. (2011). El Holocausto Español: Odio y Exterminio en la Guerra Civil y Después. Barcelona: Debate.

Reiniciar. (2006). Historia de un Genocidio: El Exterminio de la Unión Patriótica en Urabá y El

Plan Retorno. Bogotá: Corporación Reiniciar. 
Reyes, A. (2009). Guerreros y Campesinos: El Despojo de la Tierra en Colombia. Bogotá:

\author{
Grupo Editorial Norma.
}

Romero, M. (2000). Political Identities and Armed Conflict in Colombia: The Case of the Department of Córdoba, Beyond Law, 81-101.

Ron, J. (2003). Frontiers and Ghettos: State Violence in Serbia and Israel. Berkeley: University of California Press.

Ruiz, J. (2012). El Terror Rojo. Barcelona: Espasa.

Schmeidl, S. (1997). Exploring the Causes of Forced Migration: A Pooled Time-Series Analysis, 1971-1990, Social Science Quarterly, 78, 284-308.

Salehyan, I. \& Gleditsch, K. (2006). Refugees and the Spread of Civil War, International Organization, 60, 335-366.

Solé i Sabaté, J. M. (1986). Catalunya Sota les Bombes. Barcelona: Publicacions de l'Abadia de Montserrat. 
Solé i Sabaté, J M., \& Pous, J. (1988). Anarquia i República a la Cerdanya (1936-1939). El “cojo de Málaga i els fets de Bellver”. Barcelona: Publicacions de l'Abadia de Montserrat.

Solé i Sabaté, J. M., \& Villarroya, J. (1989). La Repressió a la Reraguarda de Catalunya (19361939) Barcelona: Publicacions de l'Abadia de Montserrat.

Steele, A. (2009). Seeking Safety: Avoiding Displacement and Choosing Destinations in Civil Wars. Journal of Peace Research, 46, 419-429.

Steele, A. (2010). Unsettling: Displacement during Civil Wars. PhD diss., Yale University.

Steele, A. (2011). Electing Displacement: Political Cleansing in Apartadó, Colombia. Journal of Conflict Resolution, 55, 423-445.

Unión General de Trabajadores (UGT). $\left(1931^{\mathrm{a}}\right)$. Boletín de la Unión General de Trabajadores de España Año III, $\mathrm{N}^{0} .35$, November.

Unión General de Trabajadores (UGT). (1931b). Boletín de la Unión General de Trabajadores de España Año III, Nº. 36, December. 
United Nations High Commission for Refugees (UNHCR). (2015). Global Report 2014.

http://www.unhcr.org/gr14/index.xml. Accessed: 18 September 2015.

Valentino, B., Huth, P. \& Balch-Lindsay, D. (2004). Draining the Sea: Mass Killing and

Guerrilla Warfare, International Organization, 58, 375-407.

Weidmann, N. B. (2011). Violence 'from above'or 'from below'? The Role of Ethnicity in

Bosnia's Civil War, Journal of Politics, 73, 1178-1190.

Wood, E. (2010). "Sexual violence during war: Variation and accountability." In Collective

Crimes and International Criminal Justice: An Interdisciplinary Approach, Smeulers, A.

\& Sliedregt, V. (Eds), Elies. Antwerp: Intersentia. 